\title{
The Impact of Culture on the Development of a Child
}

\author{
Ifeyinwa Cordelia Isidienu \\ http://dx.doi./org/10.4314/ujah.v18i2.9
}

\begin{abstract}
Culture performs a significant role in the development of a child. No individual develops outside the culture. The cultural background in which a child is brought up affects the totality of his life's activities. It is the culture of the people that creates the folk that stipulates reasons for action. Notions already established by an individual as a result of these formation processes are difficult to change. The formed behaviour is a symbol of identity and could also be an obstacle to adaptation. The Igbo people of Eastern Nigeria have a landmark in child's development. It is, however necessary to ascertain those cultural make-ups that could bring differences in character that marks off an individual from the rest of the same kind; and however a barrier or an advantage to human development.
\end{abstract}

\section{Introduction}

A child's development is an assemblage of the biological, emotional, social and psychological changes that occur in the child between the periods of his birth to the tail end of adolescence. The development starts from home. The cultural background in which a child grows up also performs an important role in the child's development. The parents, siblings, peer groups and elders all have parts to play in the developmental stages of a child. Although some developmental stages are the same across culture with little or no boundaries all over the world, known examples are natural phenomenon such as when it comes to the attainment of puberty. 
However, when it comes to the type of training given to an individual by the parents and those around him as stipulated by their culture; and at which age an individual is expected to perform one type of role or another, differences begin to emerge from one culture to another. The type of training and nurturing of an individual depends on the culture or race. These are foundation stages and therefore have much influence on the individual's later development in life.

During this foundation period, Igbo people perform a lot of rite, which a child must pass through. According to Anedo (2013:67) "Many of the important rites are connected with the stages of childbirth, maturity, reproduction and death. Other rites celebrate changes that are wholly cultural." Culture therefore plays a great role in the life of a child particularly among the Igbo people of eastern Nigeria. Their rites of passage are a period when an individual passes through different stages and ascends to very important changes and stages in life. Most societies of the world also have their rites of passage because of the roles it plays in the individual's life. It is therefore the culture that spells out what development is normal or not on a given stage, and what is acceptable or not. And this goes a long way in shaping an individual's behavior and the quality he is eventually made of in life and his usefulness to the society and world at large.

The significant stages of biological growth and development in the human life cycle entail the assumption of specific social status and roles. In most traditional societies, sets of complex ritual performances were marked (Nnokwe 2009:33) as attainment of each stage. In the Igbo extraction of eastern Nigeria, the marked 
rites of passage from childhood to adolescent stage that enhances child's development are enormous.

\section{Culture}

Culture is the quality in a person or society that arises from a concern for what is exceptionally good in arts, human development, other expositions of human achievements, ideas, customs, social behaviour of a society regarded collectively. According to Li \& Karakowsky (2011) "culture is a way of life of a group of people, the behaviours, beliefs, values and symbols that they accept, generally without thinking about them, and that are passed along by communication and imitation from one generation to the next." Culture is the totality of people's behaviour which has been learnt over time and handed over from generation to generation. It is the sum total of their experiences, values, language, belief system, arts and crafts, attitude, training and education, etc attained by a group of people over years and handed over to the younger generation. One is however identified by his culture. It is culture that spells out the reason and manner in which things are done.

\section{Rites of Passage as a Key to Child's Development}

As already indicated in the introduction, rites of passage is a ceremony or even series of ceremonies often very ritualized, carried out to celebrate and mark a transition in a person's life. Kanu (2015:165) indicates that "it plays a central role in the African socialization, demarking the different stages in an individual's development as well as that person's relationship and role to the border of the community". Rites of passage are a sure way of socializing an individual into the society in which he finds himself. The role behaviour is developed according to the cultural 
background and cultural expectations. Africans are religious in nature and so their rites of passage are more or less religious ceremonies. Ezenweke (2012:125) affirms that "they do not only mark the transition between an individual's life stages but they reinforce the dominant religious views and values of a culture." Some of the rites of passage enable the individual to understand his roles or what is expected of him in the society and how to relate well with others. For Akpudo (1989:2) "there are three categories of rites of passage in the Igbo people's lives. They include; rites of initiation/incorporation, rites of transition and rites of separation."

Rites of initiation or incorporation: An example is naming ceremony. This rite is performed to identify the individual in the society and welcome him or her to that stage. The child is given a name which he or she has reached and been prepared for a major rites here, and it is usually ceremonial.

Rites of transition: These are those rites performed from childhood to adolescent that will help an individual ascend well into the next phase of life. A good example is "ikpu ani" or being introduced into the secrets of masquerade -for the male child only and "iru mgbede" for the female child.

Rites of separation: Rites of separation such as birth rite etc. helps to detach an individual from his past relationship or contact he used to enjoy. Ray (1999) declared that "in the phases of human life cycle, people are metaphysically and sociologically remade into new beings with new social roles." For instance, the rites done for an infant will qualify him into becoming a human being. A child therefore develops into an adolescent to a responsible adulthood. Young adults are raised to the status of husband and 
wife and so on. Each phase of life has role expectations that must be performed. Another example is "otu ogbo" formation and entry into age grade. By this, the person is ready and initiated into the wider society as a responsible member who can be fined or asked to contribute money or physical strength for developing the society.

It has been noted that human lives are marked with changes. Among the Igbo people, there are seven phases in an individual's life that are referred to as the most important periods of change. These phases of life are conception, birth, childhood, adolescence, adulthood, death and beyond. Writing on this, William (1994:350) refers to;

Rites of passage as a ceremony held by nearly all societies to observe a person's entry into a new stage of life. Rites of passage note such occasions as conception, birth, childhood, adolescence, adulthood, death and beyond. Most rites help people to understand and accept their roles in the society and help them to learn how to treat others in new ways. Generally, the most complicated rites are those for a new role that demands a great change in behavior.

There is no doubt that rites of passage provoke a great deal of change in the life of an individual. The change enables the child to develop properly into the society in which he finds himself. Ezenweke (2012:123) reaffirms that "rites take a glaring place in African traditional life and it is an issue that forms the African lifestyle." According to her, "the various stages of human development starting from birth, puberty, marriage and death are all very important and need to be celebrated. They involved 
crossing from one stage of life to another'. Rites of passage are therefore culturally prescribed actions which accompany changes in the life cycle or the societal states (Stephen 2002). It is culture that expresses reasons for action, which must be followed judiciously, if not an individual grows outside the culture and becomes a deviant. Therefore one of the major and essential facts of rites of passage is their importance in regulating the developmental stages of the human person.

Rites are therefore initiated so that the child will have a perfect development into being a human person. Within the rites, there are do's and don'ts which must be respected. Anedo (2013:70) states that "in terms of the personal biography of individuals, this gives ritual the formative roles as the essential catalyst in major life changes and the key to the creation of identity and personhood" These rites are culturally made; they therefore shape the individual to the standard of the culture and identify the individual with the members of the same kind.

\section{Childhood Phase and Child's Development}

The birth of a new child is a thing of joy for the parents, relatives and the entire community. Childhood stage is full of activities. Nnokwe (2009:53) rightly states that "the rites of childhood introduce the child to the community. It was believed that a child would grow out of childhood and enter into adulthood physically, socially, mentally and religiously." Some of the rite is performed by the child while some are performed by the parents, relatives and the entire community. The ones performed by the child such as cutting of the teeth is to prove to everyone that he is a human being, and that he has no abomination on him, and also that he has come to live and to contribute to the society. A child is 
expected to cut the lower teeth before the upper ones. In Igbo culture area, it is believed that things should follow a cosmic order and no one has the power to thwart that order. That is why we hear certain assertions as "mmiri adighi eruchigha azu" literally translated as water does not flow from downstream upwards the source of the river. A child that cuts the upper teeth before the lower teeth has committed abomination for which the only remedy is death. Such child has no hope of developing into adolescent and to adulthood, but will end his journey in the evil forest. However since the coming of the missionaries and westernization, such practices have since been stopped. However, the idea behind this practice is that man must follow a proper way of doing things since order is the law of nature.

Other childhood activities done by the parents, relatives and the wider community are the disposal of the placenta, disposal of the navel-cord, circumcision of the child, naming ceremony, first cutting of the child's hair and so on.

The attachment between the mother and child is detached through the cutting of the placenta. Special care is taken at the disposal; it is rather buried and planted on the spot, an economic tree such as coconut, breadfruit, palm tree etc. The economic tree is a symbol characterizing the growth of the child. The navel cord also drops four or five days after the birth of the child, it is also carefully disposed as in the case of placenta. Akpudo (1989:36) states that the "navel cord is an object of special treatment, for it was a symbol of attachment to the mother." Navel cord and placenta are therefore means by which the child is attached to the mother for the sustenance of life. Detaching them is very symbolic among the Igbo people of Nigeria. Specifically, Ezenweke (2012:131) attests 
that "the cutting of the umbilical cord from the mother and the disposal of the same symbolizes detachment from the mother as the sole owner of the child and the integration into the community as a child of all the members of the community."

In Igbo land, it is a general belief that a child is owned communally. Some assertions as "nwa bu nwa ora" literally translates as, a child belong to all explains it better. For instances Mbiti (1982:120) observes that "a woman suckling a child may be called upon to suckle someone else's child." Therefore the caring and the training of a child is everybody's responsibility and every person is expected to correct a child whether they are related or not (Ogbalu 2006:19). The kind of training given ensures that the child develops morally, physically, socially, emotionally and law abiding. According to Isidienu (2014:801) "Parents train their children in general behavior and particularly in socialization which is necessary for comfortable living" She further states that;

The child starts learning the meaning of gesture by observing the mother and other members of the family as they grow up, they learn how to live, how to do certain things and the importance of both traditional religious and customary laws. The training which starts in the family later extends to the society, where both parents, elders and other members of the extended family are involved.

It is evident that the Igbo child is owned and trained communally, therefore "to establish the community ownership of the child, the umbilical cord connecting the mother and the child is cut as a sign of the incorporation of the child into the community" (Kanu 2015:168-169). Most of the childhood rites incorporates the child 
and makes him an acceptable member of the community. He is nurtured and developed in the culture of the people. These form the basics and foundation of human development.

The type of training given to an Igbo child right from inception propels him wherever he goes; he adapts to any situation and will never forget his people because of the bond in relationship. The relationship attests to communal living among the Igbo as against the individualist nature of western culture. It was also confirmed by Mbiti (1982:113) that "Physically the placenta and the umbilical cord symbolize the separation of the child from the mother"

He continued,

But the separation is not final since the two are still near each other. But the child now begins to belong to the wider circle of the society...the child has however, began his journey of being incorporated into the community, so that the separation between the individual mother and the child continues to widen as the child's integration into the wider community also increases. The child is near the mother and yet begins to get away from the individual mother; growing into the status of being "I am because we are, and since we are therefore I am".

Different societies of the world have ways and manners through which they nurse their children. Africans take up to two to three years to nurse their children. Mbiti (1982:120) confirms that "During the nursing period, the child is carried on the back or the bosom of the mother or of another female member of the village. The direct contact between mother and child gives the child a deep 
psychological sense of security" Life is full of give and take, it is very rare to find a child in Igbo community who is heart harden to the extent of harming his mother or any member of the society. It has been observed that in some communities where children are kept to stay on their own right from birth, are found to be dependent and self centered. In most cases they received no parental love and therefore have no feeling of acceptance. Such situation can lead an individual into harming his mother, father or siblings at any lest provocation without the feeling of having any blood relationship with them. Such children grow and develop into an aggressive human nature, ready to fight and do all sorts of immoral acts.

Circumcision also, being part of childhood phase is done within eight days of birth. In the past both males and females are circumcised, but recently it is only the males. During the circumcision of a male child the foreskin will be cut off. Mbiti (1975:80) rightly states that "The physical pain which the child is encouraged to endure is the beginning of training the child for difficulties and sufferings of later life." Life has never being without odds. Igbo child is made to understand this fact early in life. The bloodshed during circumcision is a covenant that symbolizes that the individual is alive and ready to be united to the community, both with the living and the dead. The act of circumcision blood makes the child a full fledge member of the society, since without it, he will continue to be an outsider.

Mostly in African societies, new born babies are not named immediately after their birth, although among the Igbo people some might be calling the baby the name of the market day in which he / she was born. The implication is that, it has not yet been 
known whether the child has come to live or not. The confirmation comes after eight or twenty-eight days of birth depending on the community. Name is given to the child through a naming ceremony rite that involves the relatives and the entire community.

Names are not given for the sake of it, such as seen in some parts of the world. Igbo people believe that one develops and acts in accordance to the name given to one. For this reason, certain things are taken into consideration before a name is given to a child. For instance, circumstances behind the birth of the child, an eventful activity in the family or clan, position of the child in the family etc. Ibewuike (2006:104) agrees that "An Igbo name was a convenient mechanism for preserving continuity and remembrance in order to identify people in their social context and tracing family descent as well." The naming of the child both humanizes and socializes him. Quarcoopome (1978:112) affirms that;

It makes him/ her member of the family and the society at large. Words and actions accompanying the ceremony are to ensure that moral values like honesty, truthfulness, openness, industry and hard work are inculcated in the newborn and as well serve as reminders to those present to keep to the right path.

After naming the child, the head of the family will take implements such as hoe, machete etc. which the community uses as a means of livelihood and touch on the child's hand and say "we use these implements as a means of livelihood, so when you grow up you will use them as such". From that period the child will be nurtured and developed according to the culture of his people in which hard work is highly upheld as a means of survival. For instance in Igbo 
assertion "aka aja aja na-ebute onu mmanu mmanu," "onye ruo o rie," meaning literally as, if one works, one will eat, is taken seriously among Igbo people.

For this reason the training given to a child in Igbo community was geared towards developing him into an honest, hardworking and industrious human being. There is no doubt in the assertion "Igbo people are industrious and hardworking people". It is what their culture stipulates which has become part of them. It is very difficult to see an Igbo man who is a beggar in the Igbo traditional society. They work effortlessly and tirelessly in order to make ends meet. They do not depend on someone for a livelihood. According to Isidienu (2014:171) "Igbo people placed a high importance in hard work; they do not only value it but also hold a hard worker on a very high esteem" They are able to live in any part of the world because of their hard working nature. They can also face and withstand challenges. They can survive anywhere they see themselves.

\section{Adolescent Phase and the Development of the Human Person}

Adolescent is the process of change from childhood to adulthood. It is a move from being dependent to independent. It is a phase filled with a lot of initiations. Metu (1987:205) refers to initiation rites as a "rite which marks the passage from childhood to adult life or what has been called 'puberty rites'. Initiation rites could accompany admission into age groups, secret societies, the ordination of a priest or medicine man or even the enthronement of a king". Initiation period is marked with seclusion period. During that period, the youth is taught various things about life, the history of the land, belief system, laws of the land, social relations and family life. According to Ezenweke (2012:134) "the act of 
seclusion symbolizes the death of old childish life while the reappearance symbolizes the resurrection into full adult ready and willing to assume adult status and responsibilities". The individual however is eager to assume adult roles and privileges with a high spirit. Some of the trainings are meant to teach them obedience and bravery. Mbiti (1975:127) affirms that "Psychologically the ritual concerned gives the individual confidence in him and stimulates him to conduct himself with courage in his new status".

Rites of passage are highly regarded in Igbo community. This was confirmed by Ezenweke (2012:133) when she states that "Because of its very important impact on community development, it is an occasion of considerable ritual," she continued, "It is primarily to welcome or introduce the new adult into the adult world with its rights, privileges and duties". The training obtained and the development attained elevates the individual to the status of being dependable, responsible, and be able to complete assigned duties. $\mathrm{He}$ is also entitled to full privileges in the community. Nnokwe (2009:65) viewes the adolescent period as that which,

Mark changes that occur in duties, responsibilities, privileges, social and economic roles and relationships with others. At adolescence, new aspirations were generated, new standards of behavior were incorporated, and new ways of learning were adopted.

The youth is initiated into masquerade institution, age grade, iru mgbede as earlier mentioned etc with some of the rites that accompanied them. For instance, the initiation into masquerade aims at making the initiates stop bad behavior that they must have learnt during the childhood stage such as lying, longer throat, 
stealing, fearfulness etc. Masquerade institution is for the male folk only; therefore it also aims at making them to be brave as men and also be able to keep secrets.

Before the adolescent enters into "mmanwu" he will first prepare himself; he will stop all bad behaviours. This is possible since the type of stories being told are mainly framed to portray the evil that might befall anyone who has not stopped his old ways of life. These stories normally put the initiates into terrible fear that they dare not indulges in evil act. They are mandated not to reveal anything about masquerade to their mothers, females or non initiates. When such stories are at the back of their mind, the initiate will never reveal any secret. All these are geared towards all round development of an individual, one that will be trustworthy, reliable, responsible, courageous and so on.

\section{Conclusion}

Child development among the Africans, Igbo people inclusive, is an integral part of the culture. A child develops from childhood into adolescent after passing through the rites attached to this stage as a means of becoming a full and normal human being that will be useful to the society. The type of training enables an individual to develop into somebody who will be able to make meaningful decisions and take actions that will move the society forward. It socializes them, and makes it easy for them to be able to adapt to situations.

This type of training and development within one's culture is what marks the difference among cultures. How one behaves is an identity that marks him off from other people. One's behaviour identifies him wherever he goes. Igbo people are known to be hard 
work and industrious; therefore the training they give, right from childhood is geared towards making an individual to become a purposeful person, that will be able to contribute meaningfully to the society. This has become however an advantage to the people since they can face life challenges wherever they found themselves.

Ifeyinwa Cordelia Isidienu

Nnamdi Azikiwe University Awka

\section{References}

Akpudo, C. M. (1989). Rites of Passage: A Case Study of Birth. Unpublished N. C. E. Project Anambra State College of Education Awka.

Anedo, O. (2013). "The Significance of Rites of Passage". Ideal. Awka: Besing Books.

Ezenweke, E. O. (2012). "Rites and Rituals in African Ontology".

Issues in African Traditional Religion and Philosophy.

Ezenweke, E. and Kanu.(eds.). Jos: Fab Anieh.

Ibewuike, V. O. (2006). African Women and Religious Change: A

Study of the Western Igbo of Nigeria. Unpublished PhD

Thesis. Sweden: Uppsala University Press.

Isidienu, I. C. (2014). "The Symbiosis in Formal and Informal Education". The Eagle of Igbo Literature. Nnyigide, N., Ezeuko, R., Nwokoye, A. and Eyisi, J. (eds.). Nimo: Rex Charles and Patrick.

Isidienu, C. I.(2014). "Igbo Traditional Occupation and Sustenance of the Modern Man”. Ideal. Awka: Besing Books. 
Kanu, I. A. (2015). A Hermeneutic Approach to African Traditional Religion, Theology and Philosophy. Jos: Fab Anieh.

Li \& Karakowsky. (2001).'Implication of Cultural Differences for Cross-Cultural Management Research and Practices." Journal of Psychology. https.//www.tamu.edu Retrieved 9/5/2016.

Mbiti, J. S. (1982). African Religious and Philosophy. London: Oxford University Press.

Mbiti, J. S. (1975). An Introduction to African Religions. London: Heinemann Educational Books.

Metu, E. I. (1987). Comparative Studies in African Traditional Religion. Onitsha: Imico.

Nnokwe, A. (2009). "Rites of Passage in Ideato-North L. G. A. Problems and Prospects". M. A. Thesis. Awka: Nnamdi Azikiwe University.

Ogbalu, F. C. (2006). Igbo Institutions and Customs. Onitsha: Varsity Industrial Press.

Quarcoopome, T. N. O. (1987). West African Traditional Religion. Ibadan: African University.

Ray, B. (1999). African Religion, Symbols and Community. Ithaca: Prentice -Hall.

Stephen,G.(2002)."RitesofPassage".RetrievedApril2016<http://ww w.soulawakening.org/teenrites/.html>

William, H. (1994). World Book. London: Rutledge and Paul Kegan. 